\title{
Kecenderungan Transformasi Hunian: Pengaruh Defisit Hunian dan Faktor-Faktor Lainnya (Studi Kasus Perumahan Bumi Karawaci)
}

\author{
Pierre Albyn Pongai, Nurahma Tresani, Liong Ju Tjung \\ Program Magister Teknik Perencanaan, Universitas Tarumanagara, Jakarta \\ Email: pierre_pongai@yahoo.com
}

\begin{abstract}
ABSTRAK
Perumahan Bumi Karawaciyang dikembangkan oleh Perumnas di Tangerang pada tahun 1979, saat ini telah mengalami banyak perubahan fisik dan pemanfaatan hunian.Secara filosofis, hunian dibangun untuk memenuhi kebutuhan normatif keluarga.Ketika hunian tidak dapat memenuhi kebutuhan tersebut, akibat perubahan siklus hidup keluarga dan kondisi sosial ekonomi keluarga, maka terjadi kondisi yang disebut defisit hunian. Ketika keluarga menyadari adanya defisit hunian, akan timbul upaya untuk mengubah huniannya, yang disebut sebagai transformasi hunian. Penelitian ini bertujuan untuk mengetahui kecenderungan transformasi hunian pada Perumahan Bumi Karawaciyang dipengaruhi oleh defisit hunian dan faktor-faktor lain. Penelitian dilakukan menggunakan metode kuantitatif dengan teknik analisis regresi logistik yang dilakukan sebanyak 3 set, yaitu regresi defisit hunian dengan 8 variabel bebas, regresi kecenderungan transformasi dengan 8 variabel bebas dan regresi kemampuan transformasi dengan 3 variabel bebas. Hasil penelitian memperlihatkan bahwa kecenderungan transformasi hunian pada Perumahan Bumi Karawaci termasuk sangat tinggi, dimana hampir semua penghuni pernah melakukan transformasi hunian dan hampir separuhnya masih ingin melakukannyalagi.Dari hasil analisis diketahui bahwa kecenderungan transformasi hunian terbukti dipengaruhi oleh persepsi defisit hunian, transformasi sebelumnya, persepsi kelengkapan fasilitas perumahan dan kualitas hubungan sosial bertetangga. Adapun defisit hunian terbukti dipengaruhi ukuran keluarga, jumlah kamar tidur dan ketersediaan ruang lain. Sedangkan kemampuan transformasi hunian terbukti dipengaruhi pendapatan keluarga. Hasil ini memperlihatkan bahwa transformasi hunian cenderung dilakukan oleh penghuni yang mempersepsikan adanya defisit hunian, penghuni yang pernah melakukan transformasi hunian sebelumnya, penghuni yang merasa nyaman dengan lingkungan perumahannya dan penghuni yang memiliki pendapatan memadai.
\end{abstract}

Kata kunci: kecenderungan transformasi hunian, defisit hunian, perumahan sederhana.

\section{PENDAHULUAN}

Penyediaan perumahan di Indonesia baru mulai dianggap penting pada Garis-garis Besar Haluan Negara (GBHN) tahun 1973(Mungkasa, 2008).Dalam mendukung program perumahan rakyat saat itu, Menteri Muda Urusan Perumahan Rakyat berkoordinasi dengan Menteri Keuangan serta bekerjasama dengan Perumnas sebagai institusi yang ditunjuk pemerintah untuk pengadaan rumah sederhana dan BTN sebagai bank nasional yang ditunjuk pemerintah untuk mendukung pembiayaan perumahan sederhana. Sejak tahun 1976-1978, Perumnas memulai pengembangan perumahan secara massal dengan konsep 'rumah inti' di tiga penjuru Jakarta, yaitu pada arah barat di Tangerang, pada arah selatan di Depok dan Bogor serta pada arah timur di Bekasi. Keempat lokasi tersebut selanjutnya berkembang menjadi kota satelit Jakarta, yang disingkat Bodetabek (Bogor-Depok-Tangerang-Bekasi), dengan dukungan tiga jaringan jalan tol utama dari Jakarta, yaitu Jalan Tol Jagorawi, Jalan Tol Jakarta-Merak dan Jalan Tol Jakarta-Cikampek.

Perumahan Perumnas di Tangerang dikenal dengan nama Perumahan Bumi Karawaci, yang dikembangkan dalam empat tahap, yaitu pada tahun 1979, 1989, 1992, dan 1996. Saat ini Perumahan Bumi Karawaci berusia sekitar 37 tahun, dimana sudah mengalami banyak perubahan kondisi fisik dan pemanfaatan hunian dari konsep awalnya.Perubahan tersebut diindikasi disebabkan akibat perkembangan kegiatan ekonomi yang menarik migrasi penduduk ke kawasan ini.

Selama ini, permasalahan perumahan di Indonesia terfokus dalam konteks backlog ketersediaan rumah, sedangkankonteks kualitas perumahan relatif masih terabaikan, seperti sosialitas 
komunitas, persepsi, aspirasi dan harapan masyarakat sebagai penghuni perumahan (Budihardjo, 1998 dalam Nurhadi 2004). Padahal hunian secara alami dirancang dan dibangun untuk memenuhi kebutuhan, normasosial dan gaya hidup orang (Mirmoghtadaee, 2009, dalam Aduwo, et al., 2013). Ketika kondisi hunian keluarga tidak dapat mengkonfirmasi normadan gaya hidup akibat perubahan kebutuhan dari waktu ke waktu, pertumbuhan siklus hidup keluarga dan perubahan pendapatan, maka terjadi kondisi yang disebut 'defisit hunian' (Tipple, 2000a, dalam Aduwo, et al., 2013). Ketika keluarga menyadari adanya defisit tersebut dan merasa hal itu penting, maka akan timbul kecenderungan untuk menghapus defisit diantaranya dengan upaya untuk mengubah hunian saat ini (Morris \& Winter, 1981, dalam Morris \& Winter, 1988).

Dalam teori lain, defisit hunian dapat dijelaskan sebagai akibat kecenderungan penyaringan ke atas terhadap persediaan perumahan. Menurut Salim (1998), di negara berkembang cenderung terjadi penyaringan ke atas terhadap persediaan perumahan. Penyaringan ke atas merupakan proses di mana perumahan yang diperuntukkan bagi keluarga berpenghasilan rendah menjadi dihuni oleh rumah tangga berpenghasilan tinggi (Kool, et al., 1989, dalam Salim, 1998). Masyarakat berpenghasilan tinggi yang menghuni hunian untuk masyarakat berpenghasilan rendah, akan merasakan adanya defisit hunian, dan karena lebih mampu maka kecenderungan transformasi hunian akan lebih tinggi.

Penelitian ini secara umum bertujuan untuk menelusuri faktor-faktor apa saja yang mempengaruhi defisit hunian dan kecenderungan transformasi hunian pada Perumahan Bumi Karawaci serta bagaimana (ada/tidak, arah dan besar) pengaruhnya. Adapun pertanyaan penelitian ini yaitu:

1. Bagaimana kecenderungan transformasi hunian yang dilakukan oleh penghuni pada perumahan sederhana di Perumahan Bumi Karawaci?

2. Apa saja faktor-faktor yang mempengaruhi defisit hunian dan kecenderungan transformasi hunian? Dan bagaimana pengaruhnya?

Melalui penelitian ini diharapkan dapat direkomendasikan hal-hal yang perlu diperhatikan dalam pengembangan perumahan dalam mengantisipasi defisit hunian yang dapat mendorong transformasi hunian.Hal ini didasarkan pada pertimbangan bahwa fenomena transformasi hunian memiliki dampak negatif terhadap penghuni, lingkungan dan kota.Selain itu, secara teoritispenelitian ini diharapkan dapat berkontribusi dalam menguji teori transformasi hunian dan defisit hunian, mengingat penelitian dengan topik tersebut masih sedikit dilakukan di Indonesia.

\section{BAHAN DAN METODE}

Morris, et al.(1976b) mengembangkan model defisit normatif perilaku konsumen, yang mengintegrasikan pendekatan sosial psikologis dan sosial budaya dalam perilaku konsumen. Model defisit hunian berasal dari pandangan konsumsi sebagai mekanisme penyesuaian untuk menjaga keseimbangan antara kebutuhan yang didefinisikan dalam hal norma-norma budaya (Tarde, 1903; Parsons dan Shils, 1954 dalam Morris, et al,.1976b), dengan tingkat konsumsi yang dicapai. Menurut Morris, et al. (1976b) defisit normatif timbul dari perbedaan antara konsumsi seperti yang ditentukan oleh norma-norma budaya dan pribadi dengan konsumsi dicapai. Konsumen termotivasi untuk melakukan pembelian baru ketika pasokan saat ini kekurangan kuantitas atau kualitas sebagaimana dinilai oleh konsumen dan/atau masyarakat (Morris, et al., 1976b).Menurut Morris \& Winter (1981) dalam Morris \& Winter (1988), defisit hunian dapat terbentuk akibat perubahan pada perumahan atau pada rumah tangga. 
Aduwo, et al. (2013) mendefinisikan transformasi hunian sebagai perubahan bentuk dan konfigurasi spasial dari unit hunian oleh penghuni dalam rangka memenuhi kebutuhan dan harapan saat ini.Transformasi hunian dimotivasi oleh sejumlah faktor yang saling terkait seperti kondisi sosial ekonomi rumah tangga, kebutuhan perumahan mereka, harapan dan kondisi hunian mereka sekarang (Aduwo, et al., 2013). Faktor lokasi dan lingkungan perumahan juga dapat mempengaruhi transformasi hunian, diantaranya adalah kondisi fisik properti di lingkungan, kualitas lingkungan dan aksesibilitas ke berbagai fasilitas perkotaan (Kirwan \& Martin, 1972, dan Gosling, et al., 1991, dalam Salim, 1998). Pendapatan keluarga adalah faktor penentu lain kemampuan keluarga untuk transformasi hunian, meskipun tidak selalu menjadi faktor signifikan (Zeigert, 1988, dalam Salim, 1998). Salim (1998) mengungkapkan bahwa motivasi utama transformasi hunian adalah kebutuhan memiliki ruang tambahan, baik untuk kebutuhan keluarga maupun tambahan pendapatan.Transformasi hunian biasa dilakukan pada perumahan yang dibangun pemerintah di banyak negara berkembang (Adegbehingbe, 2011, dalam Aduwo, et al., 2013). Di negara-negara berkembang, transformasi hunian sebagian besar dilakukan melalui inisiatif spontan pribadi (Tanaka, et al., 1998, Tipple, 2000a, dan Manalang, et al., 2002, dalam Aduwo, et al., 2013). Tipple (2000a) dalam Aduwo, et al. (2013) menemukan bahwa transformasi hunian di negara berkembang seringkali ilegal (tanpa izin).Salim (1998) menyebut transformasi hunian sebagai pengembangan informal dalam pengembangan formal.

Berdasarkan hasil tinjauan teoritis yang dilakukan, dapat dirumuskan konstruksi teoritis yang menjadi fokus penelitian sebagai berikut.

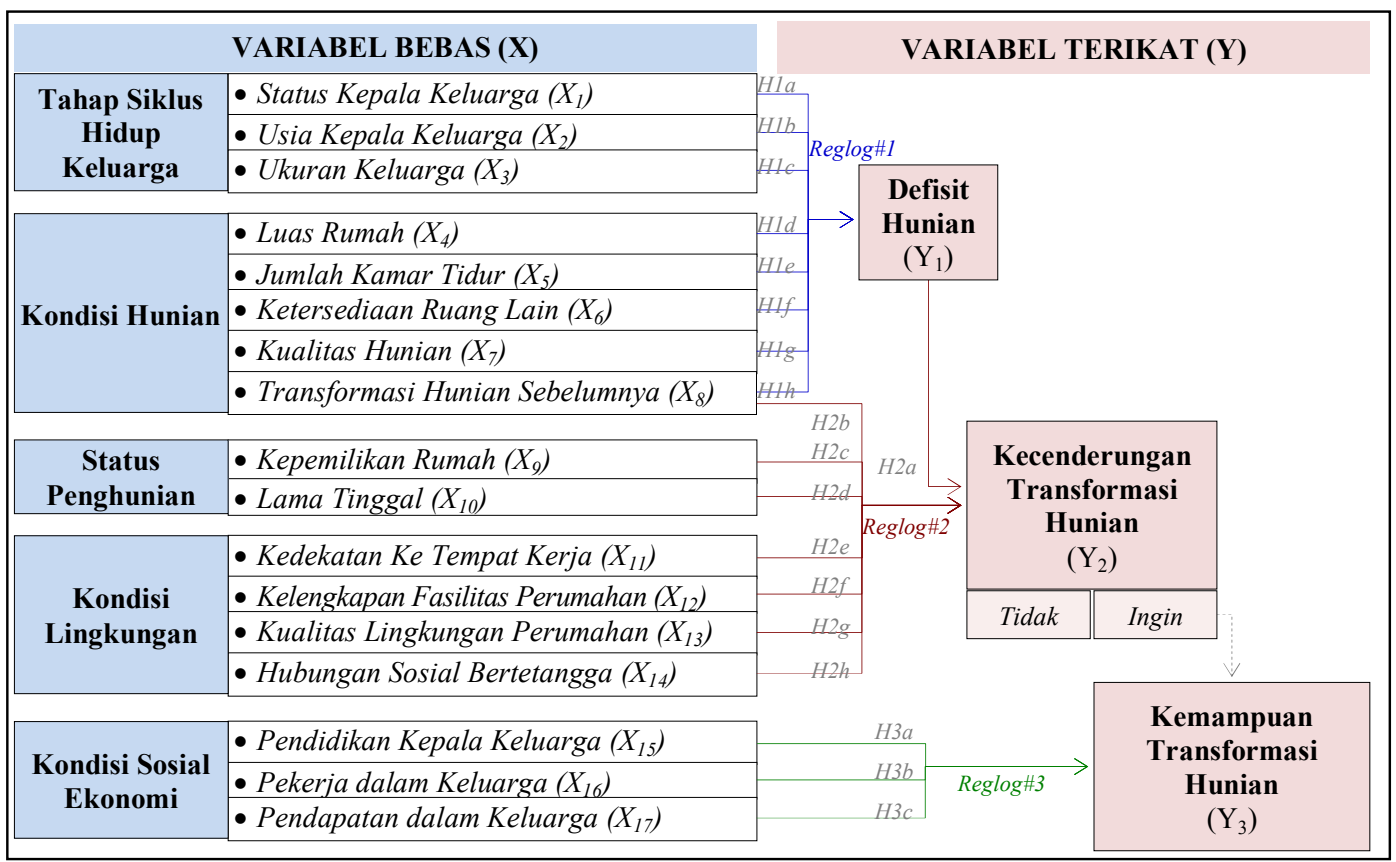

Gambar 1.Konstruksi Teoritis

Jenis penelitian ini merupakan penelitian kuantitatif yang termasuk dalam bentuk penelitian survei deskriptif.Sesuai konstruksi teoritis yang dikembangkan, dapat ditentukan variabel penelitian yang meliputi 17 variabel bebas dan 3 variabel terikat (lihat Gambar 1).Sebagai dasar pengujian, dirumuskan hipotesis penelitian yang dibagi dalam 3 kelompok, yaitu dihipotesiskan bahwa $\mathrm{X}_{1}-\mathrm{X}_{8}$ mempengaruhi $\mathrm{Y}_{1}$, dihipotesiskan bahwa $\mathrm{Y}_{1}$ dan $\mathrm{X}_{8}-\mathrm{X}_{14}$ mempengaruhi $\mathrm{Y}_{2}$, serta dihipotesiskan bahwa $\mathrm{X}_{15}-\mathrm{X}_{17}$ mempengaruhi $\mathrm{Y}_{3}$. Dengan obyek penelitian yaitu penghuni 
Perumahan Bumi Karawaci, ditentukan jumlah sampel sebesar 150 keluarga yang dipilih menggunakan metode proportionate stratified random sampling dengan pendekatan proporsi area (Perumnas 1, Perumnas2, Perumnas3 dan Perumnas4) dan proporsi tipe hunian (besar, sedang, kecil).Sesuai tujuan penelitian yaitu untuk mengetahui pengaruh antara variabel bebas terhadap variabel terikat, maka teknik analisis regresi dipilih sebagai metode analisis.Oleh karena variabel terikat dioperasionalisasikan sebagai kategorik dikotomi dan variabel terikat berdistribusi tidak normal, maka analisis regresi logistik biner dinilai paling tepat untuk pengujian penelitian ini.

\section{HASIL DAN PEMBAHASAN}

Berdasarkan hasil survei pada responden diperoleh hasil temuan sebagai berikut:

1. Terkait siklus hidup keluarga, ditemukan bahwa penghuni Perumahan Bumi Karawaci didominasi oleh keluarga tunggal serumah (84\%) dengan ukuran keluarga 3-6 orang (86\%). Walaupun demikian, ditemukan juga keluarga jamak serumah yaitu 2 keluarga serumah $(10 \%), 3$ keluarga serumah $(3,3 \%), 4$ keluarga serumah $(1,3 \%)$ dan 5 keluarga serumah $(1,3 \%)$. Hal ini tentu melampaui konsep awal kapasitas hunian, yang hanya diperuntukkan bagi 1 keluarga dengan ukuran 1-6 orang, sehingga meningkatkan potensi defisit hunian dan kecenderungan transformasi hunian.

\begin{tabular}{|c|c|c|c|c|c|}
\hline $2.0 \%$ & & $86.0 \%$ & & $10.7 \%$ & $0.7 \%$ \\
\hline 1 Orang & $=2$ Org (Pasangan) & 3-6 Org (Keluarga) & 7-10 Org (Besar) & = >10 Org (Multi) & \\
\hline
\end{tabular}

Gambar 2.Jumlah Anggota Keluarga Serumah

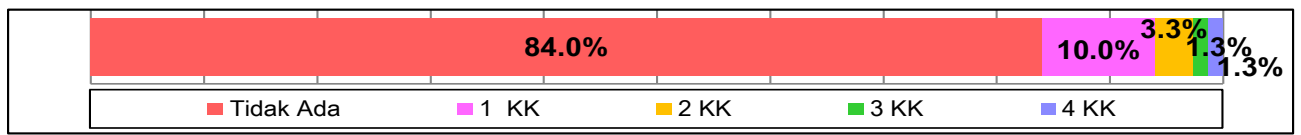

Gambar 3.Jumlah Kepala Keluarga Lain Serumah

2. Terkait kondisi sosial ekonomi keluarga, ditemukan bahwa sebagian besar penghuni Perumahan Bumi Karawacisudah tidak lagi termasuk MBR (yaitu sebesar 53,3\% dari data penghasilan keluarga lebih besar dari 5 juta rupiah per bulan atau 64,7\% dari data daya listrik yang digunakan 1300 watt ke atas). Bahkan ditemukan penghuni yang berpenghasilan hingga 300 juta rupiah per bulan dengan daya listrik 5500 watt. Hal ini membuktikan terjadinyaupward filtering of housing stock di Perumahan Bumi Karawaci, dimana perumahan untuk MBR menjadi dihuni oleh non-MBR. Kondisi ini meningkatkan potensi defisit hunian karena non-MBR menghuni hunian yang diperuntukkan bagi MBR dan meningkatkan kecenderungan transformasi hunian karena penghuni memiliki kemampuan finansial.

\begin{tabular}{|c|cccc|}
\hline $21.3 \%$ & $25.3 \%$ & $35.3 \%$ & $14.7 \%$ & $3.3 \%$ \\
\hline \hline$<3$ juta & $3-5$ juta & $5-10$ juta & $10-20$ juta & $>20$ juta \\
\hline
\end{tabular}

Gambar 4.Penghasilan Keluarga Per Bulan

\begin{tabular}{|c|c|c|c|c|c|c|}
\hline $6.0 \%$ & $.7 \%$ & & $50.7 \%$ & & $13.3 \%$ & $0.7 \%$ \\
\hline$=450 \mathrm{~W}$ & $=900 \mathrm{~W}$ & $1300 \mathrm{~W}$ & $22200 \mathrm{~W}$ & $44400 \mathrm{~W}$ & $=5500 \mathrm{~W}$ & \\
\hline
\end{tabular}

Gambar 5.Daya Listrik Yang Digunakan Di Rumah 
3. Terkait kondisi hunian, ditemukan bahwa sebagian besar hunian (84\%) sudah diperluas dari kondisi awal, yaitu dengan luas lebih besar dari 70m2 (luas standar maksimal 70m2). Selain itu, ditemukan bahwa sebagian besar hunian $(65,3 \%)$ sudah ditambahkan kamar tidur menjadi lebih dari 2 dan sebagian hunian $(40,6 \%)$ telah sudah ditambahkan toilet menjadi lebih dari 1. Hal ini memperlihatkan tingkat transformasi hunian yang telah dilakukan oleh penghuni dalam konteks perluasan hunian dan penambahan ruang.

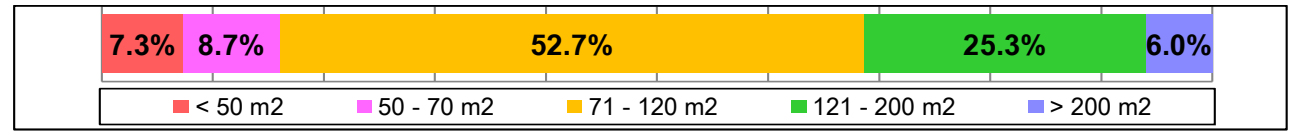

Gambar 6.Luas Bangunan Rumah

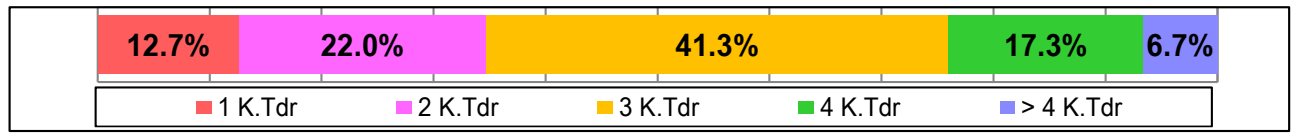

Gambar 7.Jumlah Kamar Tidur Dalam Rumah

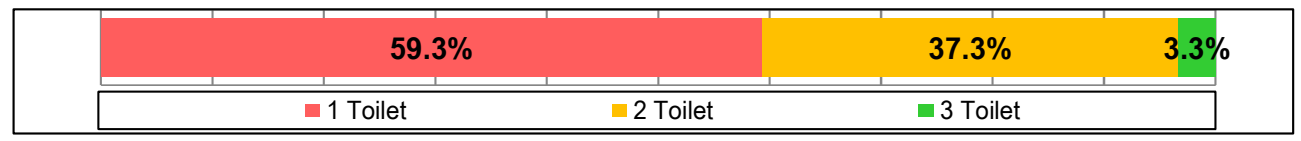

Gambar 8.Jumlah Toilet Dalam Rumah

4. Terkait defisit hunian, ditemukan bahwa sebagian penghuni $(34,7 \%)$ menilai hunian saat ini dirasakan kurang untuk memenuhi kebutuhan hunian keluarganya (disebut sebagai persepsi defisit hunian). Hal ini jauh lebih besar dari defisit riil yang diperhitungkan (jumlah anggota keluarga dikali standar hunian per kapita sebesar $9 \mathrm{~m} 2$ ),yaituhanya sebesar 3,3\%. Hal ini memperlihatkan bahwa standar atau ekspektasi penghuni yang sebagian besar non-MBR jauh lebih besar dari standar luas hunian per kapita $9 \mathrm{~m} 2$. Artinya upward filtering on housing stock meningkatkan potensi persepsi defisit hunian.

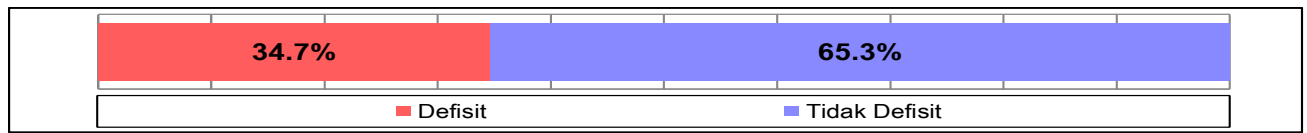

Gambar 9.Persepsi Penghuni pada DefisitHunian

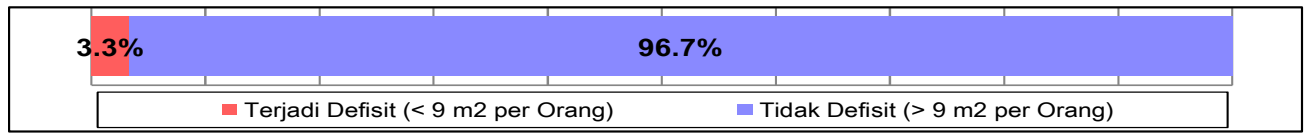

Gambar 10.Perhitungan Defisit Riil

5. Terkait kondisi lingkungan, ditemukan bahwa sebagian besar penghuni menilai kondisi lingkungan perumahan dalam kategori baik dan nyaman untuk dihuni. Sebagian besar penghuni memiliki waktu tempuh ke tempat kerja $<30$ menit $(59,3 \%)$, menilai fasilitas lingkungan relatif lengkap $(59,3 \%)$, menilai kualitas lingkungan relatif baik $(57,3 \%)$ dan menilai kualitas hubungan sosial bertetangga relatif baik $(87,8 \%)$. Kondisi lingkungan yang dinilai baik akan membuat penghuni nyaman tinggal dan tidak memilih pindah, sehingga meningkatkan kecenderungan transformasi hunian. 


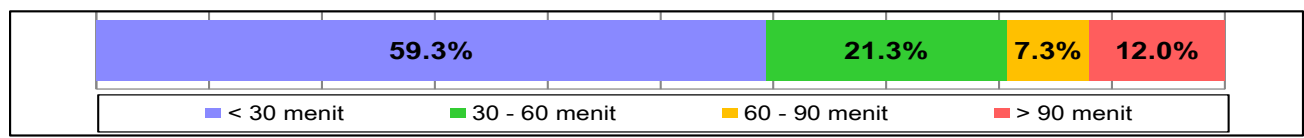

Gambar 11. Waktu Tempuh Ke Tempat Kerja

\begin{tabular}{|c|c|c|c|c|}
\hline $2.7 \% 12.0 \%$ & $26.0 \%$ & & $.0 \%$ & $13.3 \%$ \\
\hline ESangat & Tidak lengkap & Cukup & - Lengkap & - Sangat Lengkap \\
\hline
\end{tabular}

Gambar 12.Persepsi Kelengkapan Fasilitas Perumahan

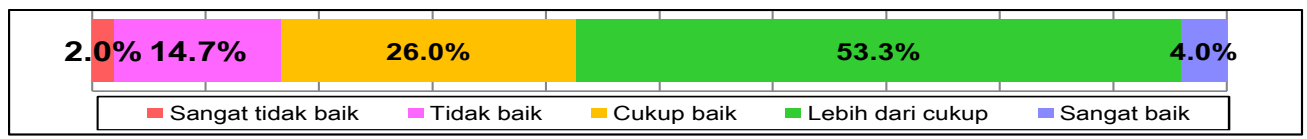

Gambar 13.Persepsi Kualitas Lingkungan Perumahan

\begin{tabular}{|c|c|c|c|c|}
\hline $3.3 \%$ & & $56.0 \%$ & & $24.7 \%$ \\
\hline Sangat tidak baik & Tidak baik & Cukup baik & Lebih dari cukup & Sangat baik \\
\hline
\end{tabular}

Gambar 14.Persepsi Kualitas Hubungan Sosial (Bertetangga)

6. Terkait transformasi hunian sebelumnya, ditemukan bahwa hampir semua penghuni Perumahan Bumi Karawaci pernah melakukan transformasi hunian sebelumnya (95,7\%). Bentuk transformasi yang pernah dilakukan antara lainmeningkatkan kualitas bangunan, menambah ruang, menambah luasan dan menambah lantai.Diketahui bahwa motivasi ekonomi pada transformasi sebelumnyarelatif cukup tinggi, yaitu untuk tambahan penghasilan melalui usaha di rumah atau menyewakan kamar.

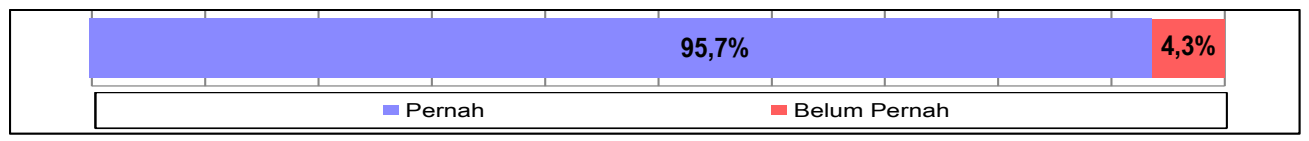

Gambar 15.Pernah/Tidak Melakukan Transformasi Hunian Sebelumnya

7. Terkait kecenderungan transformasi hunian ke depan, ditemukan bahwa hampir separuh penghuni masih ingin melakukan transformasi hunian lagi ke depannya (42,7\%). Hal ini memperlihatkan bahwa kecenderungan transformasi hunian di Perumahan Bumi Karawaci sangat tinggi, walaupun hampir semua pernah melakukan transformasi hunian namun hampir separuh masih ingin melakukannya lagi.

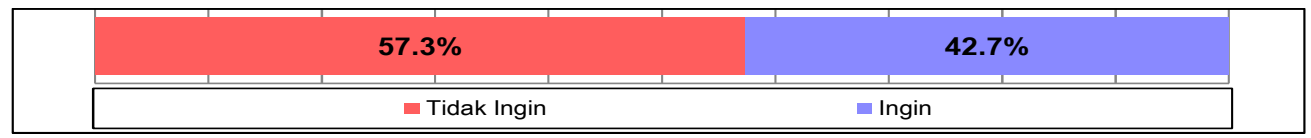

Gambar 16.Kecenderungan Transformasi Hunian Ke Depan

8. Terkait proses transformasi hunian ke depan, ditemukan bahwa penghuni Perumahan Bumi Karawaci cenderung melakukan transformasi hunian dengan dana sendiri $(93,8 \%)$, tanpa mengurus IMB (42,2\%), merancang sendiri tanpa arsitek (89,1\%), dan melaksanakan konstruksi sendiri tanpa kontraktor dengan mencari sendiri tukang bangunan (87,5\%). Hal ini memperlihatkan bahwa proses transformasi hunian oleh penghuni pada perumahan sederhana cenderung dilakukan melalui inisiatif pribadi (dana sendiri), secara ilegal (tanpa IMB) dan secara informal (tanpa arsitek dan kontraktor). Hal tentu memiliki dampak negatif pada 
kualitas bangunan yang dihasilkan dan berakibat kualitas lingkungan perumahan menjadi tidak tertata dan terkesan semrawut.

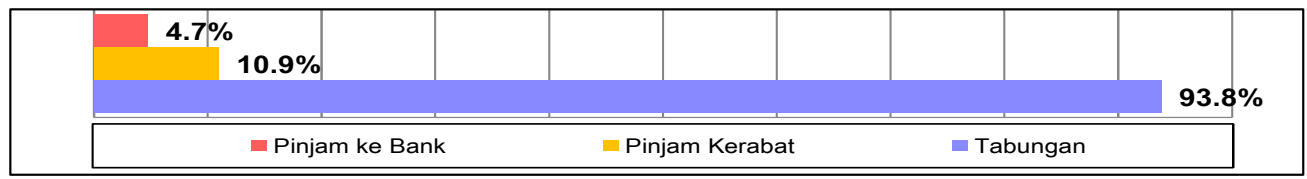

Gambar 17.Sumber Pembiayaan Untuk Transformasi Hunian

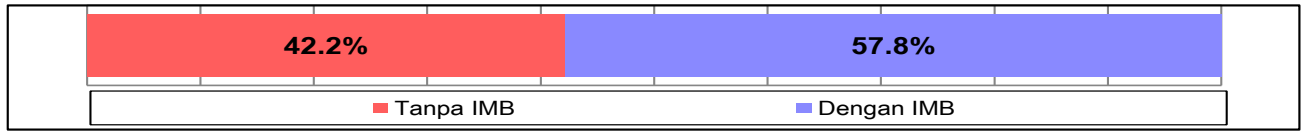

Gambar 18.Perizinan Untuk Transformasi Hunian

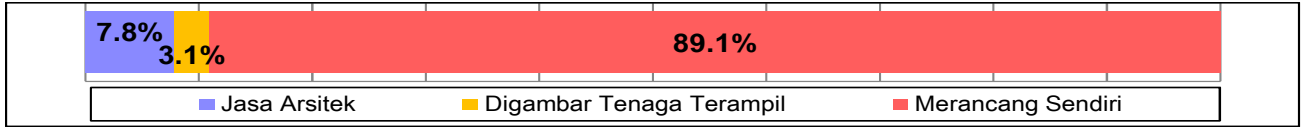

Gambar 19.Perancangan Dalam Transformasi Hunian

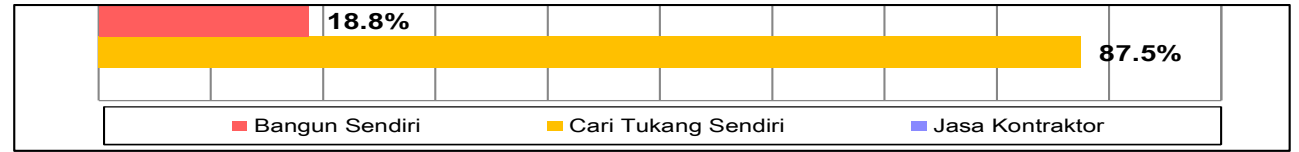

Gambar 20.Pelaksanaan Konstruksi Transformasi Hunian

Untuk membuktikan hipotesis penelitian yaitu faktor-faktor yang mempengaruhi defisit hunian, kecenderungan transformasi hunian dan kemampuan transformasi hunian, dilakukan analisis regresi logistik sebanyak 3 set. Hasil analisis regresi logistik set ke-1 membuktikan bahwa dari 8 variabel bebas, hanya 3 variabel yang terbukti mempengaruhi defisit hunian, yaitu ukuran keluarga $(+)$, jumlah kamar tidur (-) dan ketersediaan ruang lain $(+)$. Hal ini memperlihatkan bahwa potensi defisit hunian semakin besar terjadi pada keluarga yang memiliki ukuran lebih besar pada hunian dengan jumlah kamar tidur lebih sedikit dan ketersediaan ruang lain di bawah standar.

Tabel 1.Hasil Regresi Logistik Defisit Hunian (Set Ke-1)

\begin{tabular}{|rl|r|r|r|r|r|r|}
\hline Kode & \multicolumn{1}{|c|}{ Variabel } & \multicolumn{1}{c|}{ B } & \multicolumn{1}{c|}{ S.E. } & \multicolumn{1}{c|}{ Wald } & df & Sig. & Exp(B) \\
\hline $\mathrm{X}_{1}$ & StatusKK(1) & -1.851 & 4.711 & .154 & 1 & .694 & .157 \\
$\mathrm{X}_{2}$ & UsiaKK & -.027 & .039 & .458 & 1 & .499 & .974 \\
$\mathrm{X}_{3}$ & UkuranKel & 4.141 & .978 & 17.946 & 1 & .000 & 62.879 \\
$\mathrm{X}_{4}$ & LuasRmh & .010 & .013 & .616 & 1 & .432 & 1.010 \\
$\mathrm{X}_{5}$ & JmlKT & -5.848 & 1.384 & 17.846 & 1 & .000 & .003 \\
$\mathrm{X}_{6}$ & KetersediaanRLain & & & 6.261 & 2 & .044 & \\
& KetersediaanRLain(1) & 7.889 & 3.157 & 6.244 & 1 & .012 & 2668.098 \\
& KetersediaanRLain(2) & 6.331 & 2.661 & 5.659 & 1 & .017 & 561.615 \\
$\mathrm{X}_{7}$ & KualitasRmh(1) & -1.889 & 1.381 & 1.872 & 1 & .171 & .151 \\
$\mathrm{X}_{8}$ & TransformasiSblmnya(1) & 1.802 & .927 & 3.783 & 1 & .052 & 6.063 \\
& Constant & -13.178 & 4.752 & 7.691 & 1 & .006 & .000 \\
\hline
\end{tabular}

Hasil analisis regresi logistik set ke-2 membuktikan dari 8 variabel bebas, hanya 4 variabel yang terbukti mempengaruhi kecenderungan transformasi hunian, yaitu defisit hunian $(+)$, transformasi sebelumnya (-), persepsi kelengkapan fasilitas lingkungan perumahan (-), dan persepsi kualitas hubungan sosial bertetangga (-).Hal ini memperlihatkan bahwa kecenderungan 
transformasi hunian lebih besar dilakukanoleh penghuni yang mempersepsikan adanya defisit hunian, pernah melakukan transformasi hunian sebelumnyadan merasa nyaman dengan lingkungan perumahannya (mempersepsikan fasilitas lingkungan perumahan relatif lengkap dan mempersepsikan hubungan sosial bertetangga relatif baik).

Tabel 2.Hasil Regresi Logistik Kecenderungan Transformasi Hunian (Set Ke-2)

\begin{tabular}{|cl|r|r|r|r|r|r|}
\hline Kode & \multicolumn{1}{|c|}{ Variabel } & \multicolumn{1}{c|}{ B } & \multicolumn{1}{c|}{ S.E. } & \multicolumn{1}{c|}{ Wald } & df & Sig. & Exp(B) \\
\hline $\mathrm{Y}_{1}$ & Defisit(1) & 2.062 & .997 & 4.282 & 1 & .039 & 7.865 \\
$\mathrm{X}_{8}$ & TransformasiSblmnya(1) & -1.968 & .922 & 4.557 & 1 & .033 & .140 \\
$\mathrm{X}_{9}$ & Kepemilikan(1) & -.135 & 1.012 & .018 & 1 & .894 & .873 \\
$\mathrm{X}_{10}$ & LamaTgl & .012 & .038 & .105 & 1 & .746 & 1.013 \\
$\mathrm{X}_{11}$ & Kedekatan & -.007 & .010 & .467 & 1 & .494 & .993 \\
$\mathrm{X}_{12}$ & Fasilitas & -17.569 & 9397.261 & .000 & 1 & .999 & .000 \\
& Fasilitas(1) & -2.921 & .905 & 10.428 & 1 & .001 & .054 \\
& Fasilitas(2) & & & 1.449 & 2 & .485 & \\
$\mathrm{X}_{13}$ & Kualitas & -17.970 & 7450.036 & .000 & 1 & .998 & .000 \\
& Kualitas(1) & .985 & .818 & 1.449 & 1 & .229 & 2.677 \\
& Kualitas(2) & & 25.627 & 2 & .000 & \\
$\mathrm{X}_{14}$ & Sosialitas & -22.306 & 11819.500 & .000 & 1 & .998 & .000 \\
& Sosialitas(1) & -9.977 & .983 & 25.627 & 1 & .000 & .007 \\
& Sosialitas(2) & 2.653 & 1.363 & 3.786 & 1 & .052 & 14.190 \\
\hline
\end{tabular}

Hasil analisis regresi logistik set ke-3 membuktikan dari 3 variabel bebas, hanya 1 variabel yang terbukti mempengaruhi kemampuan transformasi hunian, yaitu pendapatan $(+)$.Hal ini memperlihatkan bahwa kemampuan keluarga untuk melakukan transformasi hunian lebih besar pada keluarga yang memiliki pendapatan lebih besar (dalam hal ini diketahui pendapatan lebih besar dari 7,78 juta rupiah per bulan).

Tabel 3.Hasil Regresi Logistik Kemampuan Transformasi Hunian (Set Ke-3)

\begin{tabular}{|cl|r|r|r|r|r|r|}
\hline Kode & \multicolumn{1}{c|}{ Variabel } & \multicolumn{1}{c|}{ B } & \multicolumn{1}{c|}{ S.E. } & Wald & df & \multicolumn{1}{c|}{ Sig. } & $\operatorname{Exp(B)}$ \\
\hline $\mathrm{X}_{15}$ & PendidikanKK & & & & & & \\
& PendidikanKK(1) & 1.420 & 1.451 & .957 & 1 & .328 & 4.136 \\
& PendidikanKK(2) & -1.804 & 1.338 & 1.817 & 1 & .178 & .165 \\
$\mathrm{X}_{16}$ & PekerjaDlmKel & -1.326 & .879 & 2.279 & 1 & .131 & .265 \\
$\mathrm{X}_{17}$ & PendapatanKel & .000 & .000 & 9.724 & 1 & .002 & 1.000 \\
& Constant & -8.030 & 2.683 & 8.958 & 1 & .003 & .000 \\
\hline
\end{tabular}

\section{KESIMPULAN}

Kecenderungan transformasi hunian di Perumahan Bumi Karawaci relatif sangat tinggi, dimana walaupun hampir semua rumah pernah dilakukan transformasi namun hampir separuh masih ingin melakukan transformasi hunian lagi ke depannya.Transformasi hunian pada perumahan sederhana merupakan suatu keniscayaan, yang hampir pasti akan dilakukan oleh penghuninya. Hal ini didasarkan pada proposisi bahwa transformasi hunian dilakukan untuk menyesuaikan kondisi hunian terhadap kebutuhan keluarga yang bersifat dinamis (senantiasa berubah).Sesuai proposisi tersebut, maka transformasi hunian relevan dengan perkembangan ukuran keluarga yang semakin besar dan perubahan kondisi sosial ekonomi sebagian besar penghuni Perumahan Bumi Karawaciyang tidak lagi termasuk kelompok MBR.

Dari hasil pengujian diketahui bahwa transformasi hunian cenderung dilakukan oleh penghuni yang mempersepsikan adanya defisit hunian, penghuni yang pernah melakukan transformasi hunian sebelumnya, penghuni yang merasa nyaman dengan lingkungan perumahannya (fasilitas 
dinilai lengkap dan hubungan sosial bertetangga dinilai baik) dan penghuni yang memiliki pendapatan lebih besar dari 7,68 juta rupiah per bulan. Adapun defisit hunian berpotensi lebih besar terjadi pada keluarga yang memiliki ukuran lebih besar pada hunian dengan jumlah kamar lebih kecil dan ketersediaan ruang lain di bawah standar.

Transformasi hunian yang dilakukan di Perumahan Bumi Karawaci cenderung dilakukan melalui inisiatif pribadi (menggunakan dana sendiri), secara ilegal (tanpa izin) dan secara informal (dirancang dan dibangun sendiri).Mengingat hal ini memiliki dampak negatif bagi penghuni dan kualitas lingkungan hunian, maka hasil penelitian ini menjadi masukan bagi pemerintah untuk dapat melakukan pengaturan, pengendalian dan penertiban atau penegakan peraturan.

\section{REFERENSI}

Adegbehingbe, V. (2011). Analysis of Physical Transformation of Residential Building In Selected Government Estates in South Western, Nigeria. Unpublished Ph.D Thesis. Akure, Nigeria: Federal University of Technology.

Aduwo, E. B., et al. (2013). Residents' Transformation of Dwelling Units in Public Housing Estates in Lagos, Nigeria: Implications for Policy and Practice. International Journal of Education and Research, 1(4), 5-20.

Budihardjo, E. (1998). Percikan Masalah Arsitektur Perumahan Perkotaan. Yogyakarta: Pustaka Pelajar.

Gosling, J., et al. (1991). House Extensions and Housing Market Adjustment: A Case Study Of Wokingham. Discussion.

Kirwan, R., \& Martin, D. (1972). The Economics of Urban Residential Renewal and Improvement. Working Papers. London: Center for Environmental Studies.

Kool, M., et al. (1989). A Squatter Settlement Improvement And Displacement: A Review Of Concepts, Theory And Comparative Evidence. Habitat Intemational, 13(3), 187-199.

Manalang, R., et al. (2002). A Study on Residents' Self- built Improvements at MRB Dwelling Units in Metro Manila. Journal of Asian Architecture and Building Engineering, 184, 177-184.

Mirmoghtadaee, M. (2009). Process of Housing Transformation in Iran. Journal of Construction in Developing Countries, 14(1), 69-80.

Morris, E., \& Winter, M. (1981). Housing. In D. D. Dillman, \& D. J. Hobbs, In Rural Society in the US: Issues for the 1980s (pp. 196-204). Boulder, CO: Westview.

Morris, E., \& Winter, M. (1988). Housing Adjustment, Satisfaction, and Quality/Quantity Considerations In Housing: The Case of Oaxaca De Juarez. EDRA, 19, 113-119.

Morris, E., et al. (1976b). A Normative Deficit Model of Consumer Behavior. (B. B. Anderson, Ed.) NA - Advances in Consumer Research, 03, 161-165.

Mungkasa, O. (Ed.). (2008). Pembangunan Perumahan dan Permukiman di Indonesia. Jakarta: Direktorat Permukiman dan Perumahan, Badan Perencanaan Pembangunan Nasional (Bappenas).

Nurhadi, I. (2004). Preferensi Masyarakat Dalam Memilih Perumahan Perkotaan di Kota Tangerang (Studi Kasus: Perumahan Banjar Wijaya, Poris Indah, dan Perumnas IV). Tesis Program Magister. Semarang: Program Pasca Sarjana, Magister Teknik Pembangunan Kota, Universitas Diponegoro.

Parsons, T., \& Shils, E. A. (Eds.). (1954). Toward A General Theory of Action. Cambridge: Harvard University Press.

Salim, A. (1998). Owner-occupiers Transformation of Public Low Cost Housing in Peninsular Malaysia. Thesis Report Submitted to Newcastle University. 
Tanaka, M., et al. (1998). Transitional Process of the Core Houses at Tung Song Hong Planned Settlement in Bangkok. Journal of Architecture, Planning and Environmental Engineering, 512, 93-99.

Tarde, G. (1903). The Laws of Imitation. New York: Henry Holt.

Tipple, A. (2000a). Extending Themselves: Users Initiated Transformation of Government Built Housing in Developing Countries. Liverpool: Liverpool University Press.

Zeigert, A. L. (1988). The Demand of Housing Additions: An Empirical Analysis. AREUEA Journal, 16, 479-492. 